\title{
Research on the competitiveness of six provincial capital cities in central China
}

\author{
Wanxing Li \\ Wuhan University of Technology, China, 430000 \\ 1149711346@qq.com
}

Keywords: Development of Central China, Urban competitiveness, Principal component analysis

\begin{abstract}
The central China connects east and west of China. As the political, economic and cultural center of the provinces in central China, the six provincial capitals can stimulate and promote the development of the central and neighboring regions.Studying the competitiveness of provincial capital cities in six provinces is of great significance to enhancing the competitiveness of all provinces and establishment of "The Belt and Road." The article analyzes the comprehensive competitiveness of the capital cities in the six central provinces by using the method of principal component analysis and SPSS, and finds out that among the six cities, Wuhan is the most competitive, Changsha and Zhengzhou are the second and third respectively, and Hefei,Nanchang and Taiyuan are relatively backward in their competitiveness. According to the weaknesses of the provincial capitals, some suggestions are put forward to help the Central China to speed up its development.
\end{abstract}

\section{Introduction}

With the development of economic globalization and regional integration, the interdependence among cities has been gradually strengthened, and the competition among cities has been intensified. Therefore, to strengthen the research on urban competitiveness is not only helpful for the correct understanding of the status quo and potential of cities, but also for the scientific evaluation of the advantages and disadvantages of cities, providing the necessary information for the city to formulate an appropriate regional co-opetition strategy [1-3]. The six central provinces refer to six provinces in mainland China, including Henan, Shanxi, Hubei, Anhui, Hunan and Jiangxi.Under the background of the development of Central China,the capital cities in the six central provinces must have an objective, accurate and scientific comprehensive assessment of their own development and have an objective understanding of the overall urban development level and competitiveness, In order to formulate the corresponding practical development strategy to achieve the goal of "Rise of Central China" as soon as possible, they should comprehend their own strengths and seek for the disadvantages of themselves.

Many researches on competitiveness at home and abroad, especially the research on the competitiveness of countries and industries, have been deeply studied, but the researches on the competitiveness of cities and regions are rare. This artical constructs an index system to evaluate and uses principal component analysis to empirically analyze the competitiveness of the cities,in order to promote the competitiveness and coordinated development of the capital cities in the six provinces in central china.

\section{Research method and the establishment of competitive evaluation index system}

\subsection{The establishment of competitive evaluation index system}

Based on the domestic scholars research on the evaluation index system of urban competitiveness, this paper proposes that a city with 27 specific indicators should be set up from the aspects of comprehensive economic strength, degree of opening to the outside world, human resources,science and technology,infrastructure and urban environmental conditions Competitiveness evaluation index system [4-5], as shown in Table 1. 
Table 1 Urban Competitiveness Index System

\begin{tabular}{|c|c|c|c|c|}
\hline $\begin{array}{l}\text { Comprehensive } \\
\text { economic strength }\end{array}$ & Opening up & $\begin{array}{l}\text { Talent and } \\
\text { technology level }\end{array}$ & infrastructure & $\begin{array}{l}\text { Urban } \\
\text { environmental } \\
\text { conditions } \\
\end{array}$ \\
\hline $\begin{array}{l}\text { GDP (100 million } \\
\text { yuan) } \mathrm{X}_{1}\end{array}$ & $\begin{array}{lr}\text { Total Import and } \\
\text { Export } \quad(100 \\
\text { million } \quad \text { U.S. } \\
\text { Dollars) } \mathrm{X}_{12} \\
\end{array}$ & $\begin{array}{lr}\begin{array}{l}\text { Every } \\
\text { people }\end{array} & \text { million } \\
\text { college } & \\
\text { studentsX } & \\
\end{array}$ & $\begin{array}{l}\text { Every } \quad 10,000 \\
\text { people have health } \\
\text { institutions } X_{18}\end{array}$ & $\begin{array}{l}\text { Per capita public } \\
\text { green area (square } \\
\text { meters) } X_{25}\end{array}$ \\
\hline $\begin{array}{l}\text { Per capita GDP } \\
\text { (yuan) } \mathrm{X}_{2}\end{array}$ & $\begin{array}{l}\text { The actual } \\
\text { amount } \\
\text { foreign capital } \\
\text { (100 million US } \\
\text { dollars) } \mathrm{X}_{13}\end{array}$ & $\begin{array}{l}\text { Every } 10,000 \\
\text { people have the } \\
\text { number of health } \\
\text { technology } X_{17}\end{array}$ & $\begin{array}{l}\text { Every } 10,000 \\
\text { people have the } \\
\text { number of beds in } \\
\text { public health } \\
\text { institutions } X_{19}\end{array}$ & $\begin{array}{l}\text { Comprehensive } \\
\text { utilization rate of } \\
\text { industrial solid } \\
\text { waste }(\%) X_{26}\end{array}$ \\
\hline $\begin{array}{l}\text { Tertiary Industry } \\
\text { Proportion }(\%) X_{3}\end{array}$ & $\begin{array}{ll}\begin{array}{l}\text { Foreign } \\
\text { exchange }\end{array} & \\
\text { earnings } & \text { from } \\
\text { tourism } & (100 \\
\text { million } & \text { U.S. } \\
\text { dollars) } \mathrm{X}_{14} & \\
\end{array}$ & & $\begin{array}{l}\text { Per capita urban } \\
\text { road area(square } \\
\text { meters) } \mathrm{X}_{20}\end{array}$ & $\begin{array}{l}\text { Urban greening } \\
\text { coverage }(\%) \mathrm{X}_{27}\end{array}$ \\
\hline $\begin{array}{lr}\text { Per } & \text { capita } \\
\text { disposable } & \text { income } \\
\text { of urban } & \text { residents } \\
\text { (yuan) } \mathrm{X}_{4} & \end{array}$ & $\begin{array}{l}\text { Number of } \\
\text { Inbound Visitors } \\
(10,000) X_{15}\end{array}$ & & $\begin{array}{l}\text { The number of } \\
\text { buses owned by } \\
\text { every ten thousand } \\
\text { people } X_{21}\end{array}$ & \\
\hline $\begin{array}{lr}\text { Public } & \text { Finance } \\
\text { Budget Revenues } \\
(100 \text { million yuan }) \\
\mathrm{X}_{5}\end{array}$ & & & $\begin{array}{l}\text { Post } \\
\text { Telecommunicatio } \\
\text { ns Services (100 } \\
\text { million yuan) } \mathrm{X}_{22}\end{array}$ & \\
\hline $\begin{array}{l}\text { Public Finance } \\
\text { Budget Expenditure } \\
(100 \text { million yuan }) \\
\mathrm{X}_{6}\end{array}$ & & & $\begin{array}{l}\text { Cargo turnover } \\
(100 \text { million } \mathrm{km}) \\
\mathrm{X}_{23}\end{array}$ & \\
\hline $\begin{array}{l}\text { Total investment in } \\
\text { fixed assets (100 } \\
\text { million yuan)) } \mathrm{X}_{7}\end{array}$ & & & $\begin{array}{l}\text { Passenger traffic } \\
\text { turnover } \\
(100 \text { million } \\
\mathrm{km}) \mathrm{X}_{24}\end{array}$ & \\
\hline $\begin{array}{l}\text { Total retail sales of } \\
\text { social consumer } \\
\text { goods }(100 \text { million } \\
\text { yuan) } \mathrm{X}_{8}\end{array}$ & & & & \\
\hline $\begin{array}{l}\text { Year-end savings } \\
\text { and deposits of } \\
\text { urban and rural } \\
\text { residents }(100 \\
\text { million yuan) } \mathrm{X}_{9}\end{array}$ & & & & \\
\hline $\begin{array}{l}\text { Balance of Deposits } \\
\text { of Financial } \\
\text { Institutions }(100 \\
\text { million yuan) } \mathrm{X}_{10}\end{array}$ & & & & \\
\hline $\begin{array}{l}\text { The average wage } \\
\text { of workers in post } \\
\text { (yuan) } X_{11}\end{array}$ & & & & \\
\hline
\end{tabular}

Note: The above indicator data come from the 2016 Statistical Yearbooks of various provinces and cities 


\subsection{The process of principal component analysis}

In order to analyze the competitiveness of the city, we should adopt the comprehensive index of economy, science and technology, society and environment. When building the model, we should not only reduce the number of indicators, but also minimize the loss of information and ensure a comprehensive analysis of the research object. In this paper, the principal component analysis, the collected data analysis, the steps are as follows:

1. Import raw data from 27 indicators in 6 cities into SPSS software from EXCEL.

2. The raw data of 27 indicators in 6 cities are treated in a non-dimensional way, using the standardized method (Zscores).

$\mathrm{X}^{\prime} \mathrm{ij}=\left(\mathrm{Xij}^{-} \mathrm{Xj}\right) / \sigma \mathrm{j}(\mathrm{i}=1,2,3,4,5,6, \mathrm{~J}=1,2, \ldots$ 27)

3.The standardized data is saved in the data editing window, for FactorAnalysis processing, the results shown in Table 2.

Table 2 Explains the total variance

\begin{tabular}{|c|c|c|c|c|c|c|}
\hline \multirow[b]{2}{*}{ Ingredients } & \multicolumn{3}{|c|}{ The initial eigenvalue } & \multicolumn{3}{|c|}{ Rotate squared and load } \\
\hline & total & $\%$ Of variance & $\begin{array}{c}\text { Accumulate } \\
\mathrm{d} \%\end{array}$ & total & $\begin{array}{c}\% \text { Of } \\
\text { variance }\end{array}$ & $\begin{array}{c}\text { Accumulate } \\
\mathrm{d} \%\end{array}$ \\
\hline 1 & 13.205 & 48.906 & 48.906 & 12.373 & 45.826 & 45.826 \\
\hline 2 & 5.439 & 20.146 & 69.052 & 5.122 & 18.970 & 64.795 \\
\hline 3 & 3.970 & 14.705 & 83.758 & 4.357 & 16.138 & 80.933 \\
\hline 4 & 2.879 & 10.664 & 94.421 & 3.070 & 11.371 & 92.304 \\
\hline 5 & 1.506 & 5.579 & 100.000 & 2.078 & 7.696 & 100.000 \\
\hline $\begin{array}{l}\cdots \\
27\end{array}$ & $\begin{array}{l}\cdots \\
-1.456 \mathrm{E}-15\end{array}$ & $\begin{array}{l}\cdots \\
-5.394 \mathrm{E}-15\end{array}$ & $\begin{array}{l}\cdots \\
100.000\end{array}$ & & & \\
\hline
\end{tabular}

The principle of principal component number extraction is the first $m$ principal components whose eigenvalues corresponding to the principal components are greater than 1 . The eigenvalues can be used to indicate the magnitude of the principal component influence. Therefore, the eigenvalue which is greater than 1 should be taken as the extraction standard, and the cumulative percentage of the principal components will be above $80 \%$ to $85 \%$. ${ }^{[6]}$ It can be seen from Table 3 that the initial eigenvalues of the first five components are both greater than 1 and the cumulative percentage is $100 \%$. Therefore, the number of principal components extracted is $\mathrm{m}=5$. The initial eigenvalues are $\lambda 1=13.205, \lambda 2=5.439, \lambda 3=3.970, \lambda 4=2.879, \lambda 5=1.506$, respectively.

Table 3 Rotational component matrix

\begin{tabular}{|l|l|l|l|l|l|}
\hline & \multicolumn{5}{|c|}{ Ingredient } \\
\cline { 2 - 6 } & 1 & 2 & 3 & 4 & 5 \\
\hline$Z \operatorname{score}\left(\mathrm{X}_{1}\right)$ & .925 & -.184 & .331 & .037 & .021 \\
$\mathrm{Zscore}\left(\mathrm{X}_{2}\right)$ & .691 & -.131 & .524 & -.408 & .255 \\
\hline$Z \operatorname{score}\left(\mathrm{X}_{3}\right)$ & .085 & .944 & -.284 & .138 & .034 \\
\hline$Z \operatorname{score}\left(\mathrm{X}_{4}\right)$ & .608 & -.297 & .542 & -.462 & .188 \\
\hline$Z \operatorname{zscore}\left(\mathrm{X}_{5}\right)$ & .978 & -.064 & -.130 & .147 & .040 \\
\hline$Z \operatorname{Zscore}\left({ }^{\prime}\right)$ & $\cdots$ & $\cdots$ & $\cdots$ & $\cdots$ & $\cdots$ \\
$Z$ Zscore $\left(\mathrm{X}_{27}\right)$ & -.358 & -.350 & -.533 & .175 & -.659 \\
\hline
\end{tabular}

From the composition matrix, it can be seen that $\mathrm{X}_{1}, \mathrm{X}_{5}, \mathrm{X}_{8}, \mathrm{X}_{10}, \mathrm{X}_{13}, \mathrm{X}_{14}, \mathrm{X}_{15}$ and $\mathrm{X}_{24}$ have a large load on the first principal component (comprehensive economic power), while $\mathrm{X}_{3}$ and $\mathrm{X}_{17}$ have a larger load on the second principal component $\mathrm{X}_{21}$ has a large load on the third principal component (human resources and science and technology), $\mathrm{X}_{12}$ has a large load on the fourth 
principal component (infrastructure), and $\mathrm{X}_{16}$ loads on the fifth principal component (urban environmental conditions) Larger.

4.Calculate the eigenvector matrix

The formula $F_{i}=V_{i} / \operatorname{SQR}\left(\lambda_{i}\right)$, wherei $=1,2,3,4,5$, is obtained from $\lambda_{1}=13.205 \lambda 2=5.439 \lambda 3$ $=3.970 \lambda_{4}=2.879 \lambda_{5}=1.506, \mathrm{~F}_{1}, \mathrm{~F}_{2}, \mathrm{~F}_{3}, \mathrm{~F}_{4}, \mathrm{~F}_{5}$ are eigenvector matrices.

Table 4 eigenvector matrix

\begin{tabular}{llllll}
\hline & $\mathrm{F}_{1}$ & $\mathrm{~F}_{2}$ & $\mathrm{~F}_{3}$ & $\mathrm{~F}_{4}$ & $\mathrm{~F}_{5}$ \\
\hline 1 & 0.25 & -0.08 & 0.17 & 0.02 & 0.02 \\
2 & 0.19 & -0.06 & 0.26 & -0.24 & 0.21 \\
3 & 0.02 & 0.4 & -0.14 & 0.08 & 0.03 \\
4 & 0.17 & -0.13 & 0.27 & -0.27 & 0.15 \\
5 & 0.27 & -0.03 & -0.07 & 0.09 & 0.03 \\
$\cdots$ & $\cdots$ & $\cdots$ & $\cdots$ & $\cdots$ & $\cdots$ \\
27 & -0.1 & -0.15 & -0.27 & 0.1 & -0.54 \\
\hline
\end{tabular}

5.Calculate the principal component score matrix

Multiply the eigenvector and the normalized data to get the principal component function expression:

$\mathrm{Z}_{1}=\mathrm{F}_{11} * \mathrm{ZX}_{1}+\mathrm{F}_{12} * \mathrm{ZX}_{2}+\ldots+\mathrm{F}_{1} \mathrm{p} * \mathrm{ZXp}$

$\mathrm{m}=1,2,3,4,5, \mathrm{p}=1,2 \ldots 27, \mathrm{ZX}_{\mathrm{i}}$ calculates $\mathrm{Z}_{1}, \mathrm{Z}_{2}, \mathrm{Z}_{3}, \mathrm{Z}_{4}, \mathrm{Z}_{5}$ for umproduct formula. The results are shown in Table 5.

Table 5 Central provinces six provinces capital competitiveness of the main component score

\begin{tabular}{llllll} 
& Z1 & Z2 & Z3 & Z4 & Z5 \\
\hline Wuhan & 6.984 & 0.654 & 2.912 & 0.987 & 1.978 \\
Zhengzhou & 0.94 & -0.327 & -0.356 & -0.481 & 0.85 \\
Changsha & 1.192 & -0.879 & 2.041 & 1.878 & -0.765 \\
Hefei & -1.635 & -0.048 & -3.55 & -0.672 & -3.129 \\
Nanchang & -2.824 & 1.885 & -1.206 & 1.295 & 0.253 \\
Taiyuan & -3.443 & -2.201 & -0.28 & -4.255 & 0.527
\end{tabular}

6.Use the principal component function, use principal component formula

Using the formulas $\mathrm{Z}=\mathrm{Z}_{1} * \mathrm{R}_{1}+\mathrm{Z}_{2} * \mathrm{R}_{2}+\mathrm{Z}_{3} * \mathrm{R}_{3}+\mathrm{Z}_{4} * \mathrm{R}_{4}+\mathrm{Z}_{5} * \mathrm{R}_{5}$ (Zi: principal component i score, $R_{i}$ : principal component contribution, where $i=1,2, \ldots$ 5) Sort.

Table6 Central provinces six provincial capitals comprehensive competitiveness scores and sorting

\begin{tabular}{lll} 
& $Z$ & Sequence \\
\hline Wuhan & 4.176 & 1 \\
Zhengzhou & 0.053 & 3 \\
Changsha & 0.537 & 2 \\
Hefei & -0.028 & 4 \\
Nanchang & -0.749 & 5 \\
Taiyuan & -2.736 & 6 \\
\hline
\end{tabular}




\section{The results of analysis and evaluation}

As can be seen from the above research results, among the capital cities in the six central provinces, Wuhan is the most competitive, with Changsha and Zhengzhou ranked second and third respectively. The competitiveness of Hefei, Nanchang and Taiyuan is relatively backward.

From Table 5, it can be seen that Wuhan is in the leading position among the scores of all the major components, and the data of competitiveness are all outstanding. The comprehensive competitiveness score is the first among the capital cities in the six provinces of the central china.Wuhan achieved the highest score in terms of comprehensive economic strength, talent and science and technology and urban environmental conditions, making the comprehensive development level top the capital cities of the six central provinces in the central China, and its own geographical advantages laid a good foundation for the economic development of Wuhan. However, the score of infrastructure indicators was 0.987 . For example, among the number of health institutions per 10,000 population, Zhengzhou, Changsha and Nanchang are both more than four, while Wuhan only has 3.48, which is not much superior to the other three principal components. In this regard, Wuhan still needs to be further strengthened.

Changsha scored high in overall economic strength, talent, science and technology, and infrastructure. Therefore, Changsha ranked the second in terms of overall level of development. Compared with Wuhan, Changsha is lack of economic development, while economic output, science and technology are slightly falling behind. However, its advantage lies in its index of infrastructure construction, which is far higher than that of Wuhan, indicating that Changsha has more room for development and there is not much difference between the other principal components and that of Wuhan. Therefore, Wuhan and Changsha will be major sources of power for the rise of Central China.

Zhengzhou scores more evenly across all major component indicators, though not prominent, but also do not have shortcoming because of its own absence of significant constraints in the development process. The establishment of Zhengzhou Airport Economic Comprehensive Experimental Zone also brought a good momentum of development for Zhengzhou, so its overall competitiveness ranks third. As a result of its close proximity to the Yangtze River Delta and the Yangtze River economic belt.

Hefei has certain advantages of natural location. However, its overall economic development is lagging behind. The speed of economic restructuring and industrial agglomeration are not inferior, and the quality of people's life and urban environment are to be improved.

Nanchang and Taiyuan is more lagging behind the development. Both of the five main component scores, the comprehensive economic strength and talent science and technology indicators are negative indicators of the scores, indicating that both the current economic development pressure, the introduction of qualified personnel and the development of science and technology are slow, especially in Taiyuan, the infrastructure score -4.255 points, the city infrastructure and information technology infrastructure is not well developed, so to enhance the comprehensive competitiveness is a difficult task.

\section{References}

[1] GottmanJ.MegalopolisOrthe urbanization of the Northeastern Seaboard[J].Economic Geography, 1957(33)

[2] Saskia Sassen. Cities in the Global Economy"[M].Handbook of Urban Studies.2001

[3] SCHWAB,K.The Global Competitiveness Report(2009 2010)[J].World Economic Forum. 2010

[4] ChunCai, PanWuXi, YanWeiYang.Evaluation of the comprehensive competitiveness of cities in Henan province based on principal component analysis [J]. Geographical Research and 
Development,2012(6):60-64

[5] Lu-luSHEN,Zheng-shengNZHANG,Feng, et al.Study on evaluation of urban competitiveness in Henan province based on principal component analysis [J]. Henan Science, 2011 (4): 489-494

[6] Wang Yan, Cui Yongtao. Comparative Advantage of Industrial Structure in Beijing, Tianjin and Hebei Based on Complex Network [J]Journal of Modern Management Science, 2015 (11): $15-17$

[7] You Rui. Study on City Core Competence Based on Factor Analysis - A Case Study of 12 Cities in Hubei Province at the Prefecture Level and Above [J]. Modern Commerce and Industry.2016 (02) 